has boen doing, and will warn him of pitfalls. It will also give him great satisfaction in seeing that the mathematics which he needs for his chemistry is not so very dissimilar to that used in other branches of applied mathematics; and at the end he is likely to say that a better title might have been "Molecular Physics".

C. A. Coulson

\section{REAUMUR ON STEEL}

Memoirs on Steel and Iron

By R. A. F. de Réaumur. (A translation from the original printed in 1722, by Anneliese Grünhaldt Sisco. With an Introduction and Notes by Cyril Stanley Smith.) Pp. xxxiv $+396+17$ plates. (Chicago: University of Chicago Press; London : Cambridge University Press, 1956.) 45s. not.

7 WO hundred years ago (October 17, 1757), the death occurred of René Antoine Ferchault, Seigneur of Réaumur, "whose name is to-day widely known only in connection with a thermometric scalo and a station on the Paris Métro", to use the words of Prof. C. S. Smith in his excellent introduction to this volume. The main work of his life was his biological researches, and from his investigations on the nests of wasps he might perhaps be regarded as the father of the modern wood-pulp industry. It is, however, as a result of his work on metals, confined to the ten years between 1716 and 1726 , that his chief claim to posthumous fame really depends, work from which the malleable cast iron industry directly originated. The volume under review contains the collected memoirs, first of his investigations into the production of steol by carburizing wrought iron, and, secondly, the reverse process, the decarburization of white cast iron, in his attempts to produce steel from that material.

Like so many scientific investigators of his day, Réaumur saw no line of demarcation between the discovery of new knowledge and the putting of such knowledge to practical use, and as a direct corollary of his investigations, which were for the first time strictly scientific, he introduced, although at first somewhat unsuccessfully, a new industry to France and later to the world.

Réaumur lived and worked before the age of modern science; an age which had not divorced itself from the alchemical. His thinking, as is shown throughout this book, still centred on the alchemists' 'salts' and 'sulphurs', and it is a most illuminating example of the way in which a prevailing fashion of thought can blind the researcher to what later would appear to be quite self-evident conclusions- -a warning which perhaps is not altogether inappropriate in certain directions even at the present day. In his work on the mechanism of convorting wrought iron into steel, for example, he showed beyond doubt that materials, such, for example, as lime or bone ash, which do not contain carbon, have no influenco, and that the only constant factor to be found among those which did effect tho change was carbon in some form or other. He also discovered, however, that the rate at which the conversion of iron into steel takes place may be accelerated by the presence of a salt. This fact, in view of his habits of thought, so completely blinded him to the obvious conclusion that the difference botween the original iron and the final steel lay in the carbon content of the latter, that this, one would have thought, self-evident deduction escaped him completely. It is to the 'salt' as much as to his 'sulphur' that he ascribes the effects observed, a fact which so complicates his thinking both in connexion with carburization and decarburization that the essential simplicity of the processes is completely lost.

Although the age of microscopic metallography was still in the comparatively distant future, Réaumur, with the slender facilities available to him, makes the first serious attempt to correlate structure with properties. The structure he could examine was merely that of the fractured surface, but he repeatedly makes it clear that he realizes that behind what was visibly observable lay some deeper and finer structure on which the real nature of the material ultimately depended. He was, however, able to examine in some detail the effects of carburizing wrought iron and of decarburizing white cast iron, and although the meaning of his observations so frequently escaped him, the idea of a composition gradient was clearly in his mind. He speaks, for example, of wrought iron getting into a condition close to steel. That this involved a process of diffusion he obviously realized, and that the rate of such diffusion depended on the temperature was equally clear. So far as the mechanism of the process is concerned, he appears to have believed that diffusion could produce tiny voids into which the diffusing material passed, a conception strikingly similar to the vacant lattice sites hypothesis of the modern metal physicist. It was inevitable that his work on high temperatures should have led him to consider the nature of heat itself. He knew that difforent metals had different specific heats, latent heats of fusion, and melting points, but heat to him was still a material phenomenon and he speaks, for example, of the introduction into the sample being heated of "torrents" of particles.

Whether looked at as a contribution to the historyof technology or as an account of a most interesting phase in the history of science, there can be no doubt that this book is one of outstanding importance. The translation appoars to have been done in an exemplary manner and the editor's introduetion could scarcely be improved. To translator and editor, and to the funds made available by the American Iron and Ste日l Insti. tute, we owe a volume which the publishers legitimately claim to bo "the first significant book ever devoted to the iron and steel industry".

\section{F. C. THOMpson}

\section{THE $j$ OPERATOR}

The $j$ Operator for Electrical Engineers

By Philip Kemp. Pp. vii + 135. (London : Macmillan and Co., Ltd. ; New York : St. Martin's Press, Inc., 1957.) $21 s$. net.

HLECTRICAL enginoers calculate the values and C 'phases' of alternating currents and voltagos in circuits and networks in very much the same way as they calculate steady 'direct' values, except that the values of the quantities are represented by complex numbers $(a+j b)$. They use $j$ instead of the mathema. tician's ' $i$ ' because they use $i$ for current. The basis for this system lies in the reprosentation of sinusoidally varying quantities by radial lines on a clock-face diagram, referred to as vectors, together with the use 